Program Your Microcomputer in BASIC 
Of related interest

Beginning BASIC P. E. Gosling

Continuing BASIC P. E. Gosling

Microprocessors and Microcomputers Eric Huggins 


\section{Program Your Microcomputer in BASIC}

P. E. Gosling, B.Sc., A.F.I.M.A.,

Principal Lecturer in Mathematics and Computing, Peterborough Technical College 
(C) P. E. Gosling 1981

All rights reserved. No part of this publication may be reproduced or transmitted, in any form or by any means, without permission.

First published 1981 by

THE MACMILLAN PRESS LTD

London and Basingstoke

Companies and representatives throughout the world

ISBN 978-1-349-05391-9

ISBN 978-1-349-05389-6 (eBook)

DOI 10.1007/978-1-349-05389-6

Typeset in 10/12 IBM Press Roman by

Illustrated Arts, Sutton, Surrey

The paperback edition of this book is sold subject to the condition that it shall not, by way of trade or otherwise, be lent, resold, hired out, or otherwise circulated without the publisher's prior consent in any form of binding or cover other than that in which it is published and without a similar condition including this condition being imposed on the subsequent purchaser. 


\section{Contents}

$\begin{array}{lll}\text { Preface vii } & \text { vii }\end{array}$

$\begin{array}{ll}\text { Introduction } & 1\end{array}$

$\begin{array}{ll}\text { Conversing with a Computer } & 11\end{array}$

$\begin{array}{ll}\text { Basic BASIC } & 13\end{array}$

$\begin{array}{ll}\text { Glossary of terms } & 23\end{array}$

$\begin{array}{ll}\text { Activity } 1 \text { - Use of INPUT, LET, PRINT } & 25\end{array}$

$\begin{array}{ll}\text { Activity 2 - Mathematical functions } & 27\end{array}$

Activity 3 - Literals and use of commas and semi-colons 29

Activity 4 - GOTO and IF ...THEN ... 31

Activity 5- ON ... GOTO ...

Activity 6 - AND, OR and NOT

Activity 7 - FOR ...NEXT loops 38

Activity 8 - READ and DATA 40

Activity $9-\mathrm{TAB}, \mathrm{SPC}$ and POS $\quad 42$

Activity 10 - User-defined functions 43

Activity 11 - Lists $\quad 45$

Activity 12 - Arrays 49

$\begin{array}{ll}\text { Activity } 13 \text { - Strings } & 51\end{array}$ 
Activity 14 - Subroutines

Activity 15 - Serial files

Activity 16 - General

BASIC commands

Bug-hunting, or why my programs never work first time 80

The operating system 


\section{Preface}

This book is intended to introduce the BASIC language as offered on many microcomputers to the evergrowing number of people who have access to microcomputer systems. The reader is led through the use of elementary BASIC instructions by a series of carefully selected examples, and by a series of activities, each of which deals with a single instruction, or group of instructions. No previous knowledge of computing is needed, and such computing concepts as are necessary for the understanding of the text are explained as they arise.

To use this book, as Mrs Beeton almost said, 'First get your microcomputer'. Then read as much of the manufacturer's manuals and handbooks as you can follow, which probably will be just enough to get your computer working. Manuals tend to start easy but get obscure very quickly. This is where this book comes in. Once you have read the first twenty-four pages you should be ready to start on the activities. These activities are designed to be carried out in conjunction with the manufacturer's manual. No two versions of BASIC are identical so the activities should help you to understand the manuals better and just what your particular version of BASIC allows you to do.

Activity 15 is the most difficult, but potentially the most useful, feature of your computer; always assuming that it has some sort of backing store. With backing store you can save and retrieve information at will.

Take the activities slowly and make sure you understand each example. When in doubt, return to the manufacturer's manual. When you have successfully completed the activities you are on your own and should be able to write useful and exciting programs.

The author is very grateful to his many friends in the worlds of computing and education. They have all provided a great deal of help during the production of this book. In particular must be mentioned Roy Jones, Principal of Stamford College for Further Education, for the use of the college's 380Z, the VicePrincipal of Peterborough Technical College for the use of the college's CBM 3016 and Brian Duckworth, Head of Electrical Engineering at Peterborough Technical College, for the use of his department's SWTP 6400. Last minute help from Pat Ingram of the Cambridge Computer Store was also greatly appreciated as were the suggestions for improvements from Merl K. Miller.

Thanks are extended to Mike Osler of Newtons Laboratories, Douglas Benn of Health Computers Ltd. and Peter Walker of Stukely Computer Services for 
supplying programs which ran on their machines.

Photographs are reproduced by permission of IBM(UK) Ltd., Data General Ltd., Zygal Dynamics Ltd., Memec Systems Ltd., Research Machines Ltd. and Newtons Laboratories. Finally, many thanks to my son Patrick, for performing additional photographic work in between his school work and essential motor cycle maintenance.

P. E. Gosling 